\title{
Global Pandemic Conditions and List of Possible Medications and Vaccines for the Treatment of COVID-19: A Review
}

Mohammad Mukim 1,2*
Atul Kabra
Siwani Devi $\mathbf{1}^{*}$
Mohit Chaturvedi 2
Rakesh Patel 20
1Department of Pharmacy, Kota College
of Pharmacy, Ranpur, Rajasthan, India
2Department of Pharmacy, Dr. A. P. J.
Abdul Kalam University, Arandia,
Madhya Pradesh, India
3School of Pharmacy, Raffles University,
Neemrana, Rajasthan, India
*email: mukim.life@gmail.com
Keywords:
China
Chloroquine
COVID-19
Lopinavir
SARS-CoV-2
Teicoplanin

\begin{abstract}
At the end of December 2019, a novel coronavirus was identified which caused severe acute respiratory syndrome coronavirus 2 (SARS-CoV-2) with a disease known as coronavirus disease 2019 (COVID-19). The virus first originated in the city of Wuhan in China, causing symptoms such as pneumonic plague, which began in the Wuhan region and then spread throughout the world with high transmission efficiency. Special precautions and care are needed such as leaving the public area, covering your mouth with a mask, not shaking hands, washing hands, and sanitation from time to time. Infection due to SARS-CoV-2 shows several symptoms, one of which is very often the patient shows difficulty breathing. Currently, COVID-19 has been declared a global pandemic and has almost attacked all countries in the world, including in India which has one of the largest human populations in the entire world. One of the challenges in handling COVID-19 is the unavailability of drugs or special vaccines to treat the disease, so clinical practitioners and academics are currently testing various drugs to see how they affect the COVID-19 patients. Some of the drugs tested provide effective mechanisms against SARS-CoV-2, such as chloroquine, remdesivir, lopinavir, and vaccines under development, showing efficacy to inhibit SARS-CoV-2 infection in vitro. These drugs are still being tested and are now at the forefront to combat the effects of SARS-CoV2 infection. This review article will discuss all kinds of ins and outs of SARS-CoV-2 and COVID-19, including the transmission method, how to prevent it, as well as various drugs and vaccines currently used in handling COVID-19.
\end{abstract}

Received: May 11th, 2020

Accepted: May 19th, 2020

Published: June 22nd, 2020

(C) 2020 Mohammad Mukim, Atul Kabra, Siwani Devi, Mohit Chaturvedi, Rakesh Patel. Published by Institute for Research and Community Services Universitas Muhammadiyah Palangkaraya. This is an Open Access article under the CC-BY-SA License (http://creativecommons.org/licenses/by-sa/4.0/). DOI: https:// doi.org/10.33084/ bjop.v3iSpecial-1.1397

\section{INTRODUCTION}

Novel coronavirus 2019 (nCoV-2019) are cover, positivesense single-stranded RNA viruses with a nucleocapsid of helical symmetry. Viruses that cause the severe acute respiratory syndrome coronavirus 2 (SARS-CoV-2) have widely been known to cause respiratory and intestinal infections in humans after the outbreak of "severe acute respiratory syndrome" or SARS, also known as Coronavirus disease or COVID-19 (Zumla et al., 2016; Cui et al., 2019; Li et al., 2020). The causative coronavirus of this outbreak was named SARS-CoV-2 due to its resemblance to SARS-CoV. The SARS-CoV-2 infects ciliated bronchial epithelial cells and type-II pneumocytes via angiotensin-converting enzyme 2 (ACE2) as a receptor, while MERS infects unconditional bronchial epithelial cells and type-II pneumocytes using dipeptidyl peptidase 4 (DPP4) also known as CD26 as a receptor (Zhang et al., 2020; Rockx et al., 2020).

The mechanism related to the SARS-CoV-2 infection is still unclear. However, structural analysis shows the 
possibility of the virus entering human cells through several pathways, one of which is ACE2 receptors (Zhou et al., 2020; Astuti \& Ysrafil, 2020). This newly emerged virus has much more similarity with SARS-CoV than MERS-CoV, thus bothSARS-CoV and SARS-CoV-2 may cause pathogenesis through similar mechanisms transmission of SARS-CoV to humans (Xu et al., 2020; Khan et al., 2020a). Due to this COVID-19 all over the world face pandemic conditions (Khan et al., 2020b).

This review article will discuss all kinds of ins and outs of SARS-CoV-2 and COVID-19, including the transmission method, how to prevent it, as well as various drugs and vaccines currently used in handling COVID-19. Also, this article discusses the statistical impact of COVID-19 on several countries, especially in India. This article also discusses information regarding the handling of COVID19 specifically in India, including the inspection location of SARS-CoV-2 samples that are spread throughout all regions of India. It is hoped that this review article will provide actual information regarding the current condition of the impact of COVID-19 and the therapies that are being developed to handle it.

\section{STRUCTURE AND PROTEIN FUNCTION}

In general, the structure and function of proteins from SARS-CoV-2 have similarities with other coronavirus families such as SARS-CoV and MERS-CoV although SARS-CoV-2 was found to infect more human beings than either of its predecessors (Pal et al., 2020). There are five main proteins in SARS-CoV-2 that play an important role related to the nature of pathogens in humans, consisting of the nucleocapsid $(\mathrm{N})$, spike $(\mathrm{S})$, viral envelope (E), and membrane protein (M), as well as hemagglutinin esterase (HgE) (Walls et al., 2020). The function of each protein is presented in Table I, while the structural illustration of SARS-CoV-2 as reported by Khan et al. (2020b) is presented in Figure 1.
Table I. Structure and protein function of SARS-CoV-2

\begin{tabular}{|c|c|}
\hline Structural Protein & Function of Protein \\
\hline $\begin{array}{l}\text { Nucleocapsid Protein } \\
\text { (N) }\end{array}$ & $\begin{array}{l}\text { N-Bound to RNA genome to } \\
\text { make up nucleocapsid }\end{array}$ \\
\hline $\begin{array}{l}\text { Spike Protein } \\
\text { (S) }\end{array}$ & $\begin{array}{l}\text { S-Critical for binding of host cell } \\
\text { receptors to facilitate entry of } \\
\text { host cell }\end{array}$ \\
\hline $\begin{array}{l}\text { Viral Envelope Protein } \\
\text { (E) }\end{array}$ & $\begin{array}{l}\text { E-Interacts with } \mathrm{M} \text { to form the } \\
\text { viral envelope }\end{array}$ \\
\hline Membrane Protein (M) & $\begin{array}{l}\text { M-Central organizer of } \mathrm{CoV} \\
\text { assembly } \\
\text { M-Determines shape of the viral } \\
\text { envelope }\end{array}$ \\
\hline $\begin{array}{l}\text { Hemagglutinin esterase } \\
\qquad(\mathrm{HgE})\end{array}$ & $\begin{array}{l}\text { It is a glycoprotein that } \\
\text { certain enfold viruses possess, it } \\
\text { is used as invading function }\end{array}$ \\
\hline
\end{tabular}

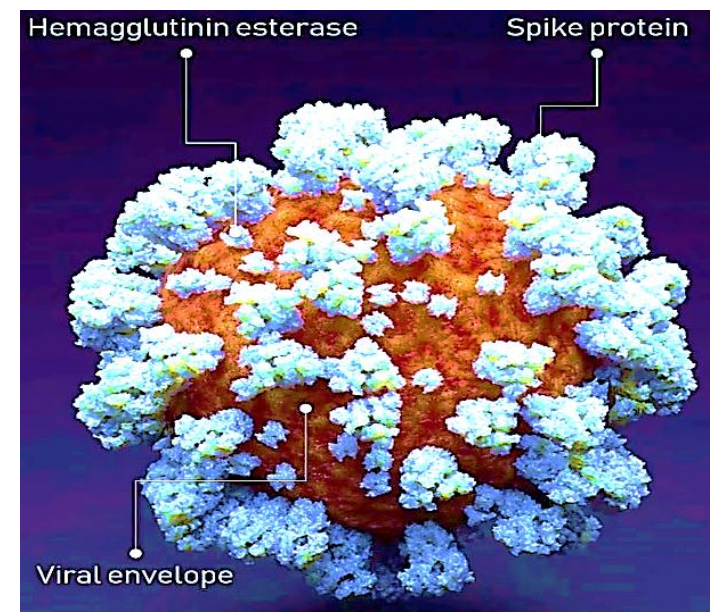

Figure 1. The structure of SARS-CoV-2 (Khan et al., 2020b)

\section{SYMPTOMS, PREVENTION, AND MODE OF TRANSMISSION}

\section{Symptoms of COVID-19}

In general, COVID-19 can affect anyone, young or old, male or female, in all parts of the world. However, the symptoms shown between individuals are not always the same (Yi et al., 2020). Some individuals with certain conditions show a tendency for more severe symptoms and need treatment in hospitals, while some people do not cause clinical symptoms at all. This disease also causes more symptoms in the elderly and people with special underlying health conditions such as the presence of certain congenital diseases (Singhal, 2020). However, 
most people infected with COVID-19 experience the following symptoms:

1. Fever

2. Common cold

3. Cough

4. Sore throat

5. Fatigue

6. Shortness of breath

7. Running nose (Wang et al., 2020b).

\section{Prevention of COVID-19 infection}

The SARS-CoV-2 is known to be transmitted directly from human to human. At this point, the best way to prevent the spread of COVID-19 is to minimize direct contact with other humans (Yuen et al., 2020). Some ways can be done, including avoiding traveling outside the house or to public places if there is no urgent need, taking a safe distance of several meters with others if forced to interact, and increasing the body's immune system by routinely exercising and consuming various vitamins (Ali \& Alharbi, 2020). The following are some precautions that can be taken to prevent or minimize the spread of COVID-19, including:

1. Wash your hands thoroughly with soap and water for at least 20 seconds.

2. Avoiding touching the nose, mouth, eyes, or other parts of the face except after washing hands or using a hand sanitizer.

3. Use hand sanitizers that contain antiseptics such as alcohol with at least a $70 \%$ concentration if soap and water are not available

4. Maintain a safe distance of at least 2 meters from others, especially those who are coughing and sneezing.

5. Avoid public places as much as possible, especially those that do not allow to maintain a safe distance such as traditional markets, public transportation, and others.
6. Avoid close contact with people who are sick with any disease, especially those who are undergoing treatment at the hospital (Omer et al., 2020).

Elderly aged over 65 years must fully avoid traveling outside the house because of a higher risk of infection. This is related to the immune system that has begun to decline, so it is necessary to take more intensive precautions to avoid being infected with COVID-19. In general, the principles of prevention of transmission of COVID-19 are stated by WHO as physical distancing, which is as much as possible to keep a safe distance from others (Djalante et al., 2020).

\section{Mode of transmission COVID-19}

In general, a typical symptom of COVID-19 is a respiratory infection that is transmitted through respiratory droplets. The SARS-CoV-2 can spread between people who are close by through respiratory droplets or direct contact routes that were previously in contact with droplets (Peng et al., 2020). Transmission from a droplet when someone makes close contact within a distance of 1 meter or less with someone who coughs or sneezes can be inhaled directly through the nose or mouth, especially if the person is not wearing a mask or face shield (Guner et al., 2020). Therefore, in addition to maintaining a safe distance, protecting the mouth, nose, and eyes from possible exposure to respiratory droplets is also mandatory, especially in areas known to have positive cases of COVID-19 (Liu et al., 2020a). In addition to being transmitted directly through droplets, a person can also be infected if it touches the surface of an object that has been exposed to droplets containing SARS-CoV-2 for some time. SARS-CoV-2 itself is known to have a long lifetime on several surfaces of the object, so washing hands becomes mandatory after touching the surface of any object. Also, you can use waterproof gloves when on the move and take it off when it touches the face (Morawska \& Cao, 2020). The 
incubation period for COVID-19 itself varies between individuals, with an average of five to six days and can be as long as 14 days (Lauer et al., 2020).

\section{DRUGS AND VACCINES ON TREATMENT OF COVID-19}

\section{Chloroquine}

Chloroquine is a quinoline compound that has a structure similar to quinine, an alkaloid compound found in the Chinchona sp. plant, and used as an antimalarial drug. The US uses chloroquine as one of the treatment options for COVID-19. Its use has been approved by the FDA to be tested as a treatment for COVID-19. Chloroquine is being tested in various clinical trials conducted by government agencies and academic institutions. Chloroquine is known to inhibit viral infections by increasing the endosomal $\mathrm{pH}$ needed for viral/cell fusion, inhibiting entry through changes in glycosylation of ACE2 receptors and spike proteins (Megarbane, 2020; Wang et al., 2020d).

\section{Hydroxychloroquine}

Hydroxychloroquine is a hydroxy derivative of chloroquine which has antimalarial activity such as chloroquine but with fewer side effects. Like chloroquine, hydroxychloroquine inhibits entry of SARS-CoV-2 through changing the glycosylation of receptors-ACE2 and spike protein viruses (Gautret et al., 2020; Liu et al., 2020b).

\section{Teicoplanin}

Teicoplanin is an antibiotic (glycopeptide) marketed by Sanofi-Aventis routinely used to treatment of bacterial infection. it was found to be active in vitro against SARS$\mathrm{CoV}$, has joined the list of molecules that could be used as 4 therapeutic arsenals against COVID-19. According to the current study showed that this activity was conserved on SARS-CoV-2 (the target sequence that serves as the cleavage site for cathepsin $\mathrm{L}$ is conserved among SARS-CoV spike protein). Based on data of teicoplanin usage in the treatment of infectious diseases, with further newly investigation of the antiviral effect of this molecule on SARS-CoV-2 and suggest teicoplanin as another potential alternative for the treatment of COVID19. Teicoplanin works by inhibiting cell wall synthesis (Baron et al., 2020).

\section{Remdesivir}

Remdesivir is a broad-spectrum antiviral medication developed by the biopharmaceutical company Gilead Sciences and now being tested in two phases III randomized clinical trials in Asian countries against the COVID-19. The trials are performing on 750 and more patients in a randomized at multiple hospitals in Wuhan, the epicenter of the novel coronavirus outbreak. The results from the trials are expected to be coming maybe in a few weeks. According to a report by remdesivir, when administered to a coronavirus patient in the US, appeared to have improved the clinical condition of patients (Wang et al., 2020c; Norrie, 2020).

\section{Favilavir}

Favilavir is an antiviral medication used to treat influenza in Japan, being developed and manufactured by Toyama Chemical and used as a treatment for coronavirus in Japan. Favilavir or favipiravir was formerly called fapilavir. The drug has reportedly shown efficacy in treating the disease with minimum side effects in a clinical trial with 70 patients. The clinical trial is being conducted in Shenzhen, Guangdong province (Zhai et al., 2020).

\section{Lopinavir-ritonavir}

The combination of lopinavir and ritonavir (also known as Kaletra) developed by AbbVie, Inc. was originally designed to treat HIV. In the clinical trial, the patient was 54 years old and was given a combination of these two drugs and had a significant source of reduction in his 
SARS-CoV-2 levels (Guo et al., 2020). However, a recent report by Cao et al. (2020) mentioned that in hospitalized adult patients with severe COVID-19, no benefit was observed with lopinavir-ritonavir treatment beyond standard care.

\section{Gimsilumab}

Gimsilumab (formerly known as MORAb 022) developed by Roivant Sciences is a fully human monoclonal antibody that acts on the granulocytemacrophage colony-stimulating factor (GM-CSF). The drug makes targets on GM-CSF, which is a proinflammatory cytokine found in high levels in the serum of COVID-19 patients. Targeting on GM-CSF is realize to reduce lung damage and reduce the mortality rate in COVID-19 patients (Tay et al., 2020).

\section{Fusogenix DNA vaccine}

The Fusogenix DNA vaccine was developed by Entos Pharmaceuticals using a fusogenix drug administration platform to treat COVID-19 infections. The Fusogenix DNA drug delivery platform is a proteo-lipid vehicle that introduces genetics directly into cells. Fusogenix DNA in the development of additional load containing several epitope proteins derived from several SARS-COV-2 proteins, which will stimulate the immune response in the body to prevent and control COVID-19 infections (ElAziz \& Stockand, 2020).

\section{ChAdOx1 nCoV-19 vaccine}

ChAdOx1 $\mathrm{nCoV}-19$ is an adenovirus vaccine vector developed by the University of Oxford which is a weakened version of a common cold virus (adenovirus) that causes infections in chimpanzees, that has been genetically changed so that it cannot replicate in humans. The vaccine in a clinical trial planned for treatment for COVID-19. Approximately 510 Patients aged between 18 to 55 years will be registered for the study (Doremalen et al., 2020).

\section{AdCOVID}

AdCOVID is a single-dose, intranasal vaccine candidate designed to protect against COVID-19, developed by Altimmune, Inc. in collaboration with the University of Alabama at Birmingham. It currently carrying out immunogenicity studies after, which phase one clinicaltrial material, will be developed. Scientists conducted pre-clinical animal studies and phases one clinical-trial in the third quarter of 2020 (World Health Organization, 2020).

\section{TJM2}

TJM2 is a monoclonal antibody designed to neutralize GM-CSF which is responsible for acute and chronic inflammation and developed by I-Mab Biopharma. It is a treatment for cytokine storm in patients suffering from a severe condition of novel coronavirus infection. This TJM2 may be used for treating COVID-19 and still undergoing preclinical and clinical trials. One-arm clinical trials, open-label trials will assess the ability of TJM2 in reducing cytokine levels, including GM-CSF, in people with severeSARS-CoV-2 infection in South Korea (Pawar, 2020).

\section{AT-100}

AT-100 is a new recombinant human protein rhSP-D (an engineered version of endogenous protein) that reduces inflammation and infection while modulating the immune response to break the cycle of injury and inflammation. AT-100 was developed by Airway Therapeutics, Inc. as a treatment for COVID-19. AT-100 has shown efficacy in pre-clinical studies in reducing inflammation and infection in the lungs, while also generating multiple immune responses against various respiratory diseases (Sandra, 2020).

\section{TZLS-501}

TZLS-501 is a monoclonal antibody for the treatment of Novel Coronavirus developed by Tiziana Life Sciences. This monoclonal antibody is a human IL-6R (anti- 
interleukin-6 receptor). TZLS-501 prevents lung damage and increases IL-6 levels. This drug works by binding to IL-6R and depleting the amount of IL-6 that circulates in the body, thereby inhibiting chronic lung inflammation (Tiziana Life Sciences, 2020; Duddu, 2020).

\section{OYA1}

OYA1 is an antiviral compound developed by OyaGen, Inc. and has strong antiviral activity against coronavirus in the laboratory-based assays against the coronaviruses SARS-CoV-2 and MERS-CoV and also is a dual targetspecific antiviral against filoviruses such as Ebola virus. It was found to be more effective in inhibiting SARS-CoV2 from replication in cell culture. OYA1 is planned to be further investigated to determine the efficacy of treating coronavirus (Pawar, 2020).

\section{BPI-002}

BPI-002 by BeyondSpring, Inc. is a novel orally administered small molecule agent that is a potent $\mathrm{T}$-cell co-stimulator. BPI-002 is indicated for treating different infections including COVID-19. It can activate CD4+ helper $\mathrm{T}$ cells and CD8+ cytotoxic $\mathrm{T}$ cells generating an immune response to the body. It gives a better response if combined with another COVID-19 vaccine and can generate long-term protection against viral infections (BeyondSpring, 2020; Duddu, 2020).

\section{NP-120}

NP-120 or Ifenprodil by Algernon Pharmaceuticals is a small molecule given orally, originally developed by Sanofi to treat disorders of peripheral circulation. NP-120 is also a potential treatment for COVID-19. NP-120 is an N-methyl-d-aspartate (NDMA) glutamate receptor antagonist specifically targeting NMDA-type 2B (Glu2NB) subunits. NP-120 also shows agonist activity for the Sigma-1 receptor, a companion protein that is regulated during endoplasmic reticulum stress (Algernon Pharmaceuticals, 2020; Duddu, 2020).

\section{APN01}

APN01 is a recombinant form of human angiotensinconverting enzyme 2 (ACE2) that has previously been tested in phase 1 and 2 trials for acute lung injury (ALI) and pulmonary artery hypertension (PAH) involving 89 patients. APB01 was developed by the University of British Columbia and APEIRON Biologics is being tested in China in a phase 1 pilot trial as a treatment for COVID19. APN01 is on researching for treating SARS. The research that the ACE2 protein was the main receptor for the SARS virus. The clinical trial will test the drug's efficacy in reducing the viral load in patients (APEIRON Biologics, 2020; Duddu, 2020).

\section{mRNA-1273}

mRNA-1273 developed by Moderna and Vaccine Research Center is a novel lipid nanoparticle (LNP)encapsulated mRNA-based vaccine that encodes for a full-length, prefusion stabilized spike (S) protein of SARS-CoV-2. Enrollment will occur at up to 3 domestic clinical research sites. The vaccine has been manufactured for phases I human clinical trial. The trial began in mid-March at the Washington Health Research Institute in Seattle, Washington. A total volunteer of 45 males and females aged between 18 and 45 have been enrolled for the clinical trial. The volunteer will be divided into three cohorts who will be administered 25 $\mu \mathrm{g}, 100 \mu \mathrm{g}$, or $250 \mu \mathrm{g}$ dose 28 days apart (Moderna, 2020).

\section{TNX-1800}

TNX-1800 is a modified horsepox virus and is designed to express proteins from SARS-CoV-2. TNX-1800 was developed by Tonix Pharmaceuticals in a strategic collaboration with Southern Research. It is believed that horsepox has the potential to be a vector for vaccines to protect against other infectious agents. The new research collaboration will develop and test a potential horsepox vaccine that expresses protein from SARS-CoV-2 to protect against COVID-19 (Tonix Pharmaceuticals, 2020). 


\section{Brilacidin}

Brilacidin (PMX30063) is a polymer-based antibiotic currently in human clinical trials and represents a new class of antibiotics called host defense protein mimetics, or HDP-mimetics, which are non-peptide synthetic small molecules modeled after host defense peptides (HDPs) (Mensa et al., 2014). Brilacidin is currently developed by Innovation Pharmaceuticals and shown antiinflammatory, antibacterial, and immunomodulatory properties in several clinical trials. These drugs for inflammatory bowel disease and oral mucositis in cancer patients. Innovation Pharmaceutical has signed two material transfer agreements with a university and 12 biocontainment laboratories in the US to evaluate brilacidin as COVID-19 therapy (Innovation Pharmaceuticals, 2020; Duddu, 2020).

\section{BXT-25}

BXT-25 is an anti-necrosis drug that carries oxygen to tissues when the flow of blood is blocked. BXT-25 has been developed by Bioxytran, Inc. as a treatment for Acute Respiratory Distress Syndrome (ARDS) in latestage patients infected with the SARS-CoV-2. The drug may help in transport oxygen to the vital organs and enable the patient to recover and survive. The treatment will allegedly offer enough time for the patient to recover and, over time, the body's immune system will destroy the virus (Bioxytran, 2020; Duddu, 2020).

\section{Galidesivir}

Galidesivir by Biocryst Pharmaceuticals, Inc is an antiviral drug, an adenosine analog, and broad-spectrum antiviral in advanced development for the treatment of viruses that pose a threat to health and national security, including SARS-CoV-2. Tests show that galidesivir is safe and generally well-tolerated through evidence in clinical phase 1 safety and pharmacokinetic trials by the route of intravenous and intramuscular administration in healthy subjects. In studies using test animals, galidesivir shows survival benefits against a variety of serious pathogens (Biocryst Pharmaceuticals, 2020).

\section{REGN3048-3051}

REGN3051 and REGN3048 developed by Regeneron Pharmaceuticals are two human monoclonal antibodies that neutralize MERS-CoV by reducing viral replication in mice expressing human DPP4 based on prophylactic and therapeutic treatment (de Wit et al., 2018). REGN3048 and REGN3051 are being studied for their activity against coronavirus infections in the first clinical trials in humans sponsored by the National Institute of Allergy and Infectious Diseases (NIAID). Clinical trials of this drug will be studied in 48 patients, in which both antibodies bind to the $S$ protein from MERS-CoV (Regeneron Pharmaceuticals, 2020; Duddu, 2020).

\section{Kevzara}

Kevzara or sarilumab developed by Regeneron Pharmaceuticals-Sanofi is a fully human monoclonal antibody, in phase two leading to three clinical trials in patients with severe COVID-19 infection. Kevzara is approved for the treatment of rheumatoid arthritis and is known to block the interleukin-6 (IL-6) pathway, which causes an overactive inflammatory response in the lungs of COVID-19 patients (Regeneron Pharmaceuticals, 2020; Magro, 2020; Duddu, 2020).

\section{SNG001}

SNG001 developed by Synairgen Research is the IFN- $\beta$ 1a formulation for direct delivery to the lungs through nebulization. This is a neutral $\mathrm{pH}$ and free of mannitol, arginine, albumin, and human serum, making it suitable for direct inhalation delivery to the active site. SNG001 can be proven to have an important role in the current outbreak COVID-19 epidemic, especially concerning high-risk populations very affected by this virus and the like (Synairgen Research, 2020; Mantlo et al., 2020; Duddu, 2020). 


\section{TAK-888}

TAK-888 is an anti-SARS-CoV-2 polyclonal hyperimmune globulin (H-IG) considered to treat highrisk individuals which developed by Takeda. TAK-888 began to enter the development phase of an anti-SARSCoV-2 H-IG to treat individuals at maximum risk with SARS-CoV-2. Hyperimmune globulin is a plasma derivative therapy that has previously been proven effective in the treatment of severe acute viral respiratory infections and can be the treatment of choice for COVID19 patients (Takeda, 2020).

\section{COVID-19 CONFIRMED CASES IN WORLDWIDE AND INDIA}

With almost all countries in the world affected by the COVID-19 pandemic, some countries show relatively more severe conditions than others. While some countries choose to do partial or total lockdowns, certain countries choose not to impose strict restrictions until they do not impose any restrictions. This condition causes the spread of COVID-19 in several countries, especially those in Europe and America far higher than others. In addition to the restriction policy factors adopted by the local government, the population of citizens from each country also has an influence on the high number of COVID-19 cases in several countries. According to the Worldometer (2020), a database that reports the detailed information and increase in COVID-19 confirmed cases in all countries in the world in detail and is updated daily, these countries have the highest number of COVID-19 cases, as presented in Table II. The interesting thing is that of the 10 countries, only Iran is in Asia, which incidentally is the continent where the COVID-19 case was first discovered. These points reinforce that the COVID-19 epicenter is currently on the continents of Europe and America.
Table II. The number of COVID-19 confirmed cases worldwide per May 11 $11^{\text {th }}, 2020$ (Worldometer, 2020)

\begin{tabular}{clrr}
\hline No & Country name & $\begin{array}{c}\text { Confirmed } \\
\text { cases }\end{array}$ & Death \\
\hline 1 & USA & $1,271,645$ & 76,916 \\
2 & Spain & 224,390 & 26,621 \\
3 & Russian Federation & 221,344 & 2,009 \\
4 & United Kingdom & 219,187 & 31,855 \\
5 & Italy & 219,070 & 30,560 \\
6 & Germany & 169,575 & 7,417 \\
7 & Brazil & 155,939 & 10,627 \\
8 & Turkey & 138,657 & 3,786 \\
9 & France & 137,073 & 26,338 \\
10 & Iran & 107,603 & 6,640 \\
\hline
\end{tabular}

On the other hand, India as one of the countries with the second most populous population in the world after China, when this article was written was indeed not included in the top 10 countries with the highest number of COVID-19 cases. One of the reasons is the Indian government's policy which immediately implemented a total lockdown when the number of COVID-10 confirmed cases in India began to increase sharply. However, seeing a large number of population in India and the trend of the increasing number of confirmed cases quickly, it is not impossible the number of COVID19 cases in India can increase rapidly in the next few weeks. Still based on the Worldometer (2020), the number of COVID-19 confirmed cases in each state throughout India is presented in Table III. As of May $11^{\text {th }}, 2020$, the highest number of cases were reported in the state of Maharashtra, with the number of cases nearly three times more than Gujarat as the state with the second-most cases.

Table III. The number of COVID-19 confirmed cases in India per May $11^{\text {th }}, 2020$ (Worldometer, 2020)

\begin{tabular}{clrr}
\hline No & $\begin{array}{c}\text { Name of States/ } \\
\text { Union territories }\end{array}$ & $\begin{array}{c}\text { Confirmed } \\
\text { cases }\end{array}$ & Death \\
\hline 1 & Maharashtra & 22,171 & 832 \\
2 & Gujarat & 8,194 & 493 \\
3 & Tamil Nadu & 7,204 & 47 \\
4 & Delhi & 6,923 & 73 \\
5 & Rajasthan & 3,814 & 107 \\
6 & Madhya Pradesh & 3,614 & 215 \\
7 & Uttar Pradesh & 3,467 & 74 \\
8 & Andhra Pradesh & 1,980 & 45 \\
9 & West Bengal & 1,939 & 185 \\
10 & Punjab & 1,823 & 31 \\
11 & Telangana & 1,196 & 30 \\
\hline
\end{tabular}




\begin{tabular}{|c|c|c|c|}
\hline 12 & Jammu and Kashmir & 861 & 9 \\
\hline 13 & Karnataka & 848 & 31 \\
\hline 14 & Haryana & 703 & 10 \\
\hline 15 & Bihar & 696 & 6 \\
\hline 16 & Kerala & 512 & 4 \\
\hline 17 & Odisha & 377 & 3 \\
\hline 18 & Chandigarh & 169 & 2 \\
\hline 19 & Jharkhand & 158 & 3 \\
\hline 20 & Tripura & 150 & 0 \\
\hline 21 & Uttarakhand & 68 & 1 \\
\hline 22 & Assam & 63 & 2 \\
\hline 23 & Chhattisgarh & 59 & 0 \\
\hline 24 & Himachal Pradesh & 55 & 2 \\
\hline 25 & Ladakh & 42 & 0 \\
\hline 26 & $\begin{array}{l}\text { Andaman \& Nicobar } \\
\text { Islands }\end{array}$ & 33 & 0 \\
\hline 27 & Meghalaya & 13 & 1 \\
\hline 28 & Puducherry & 9 & 0 \\
\hline 29 & Goa & 7 & 0 \\
\hline 30 & Manipur & 2 & 0 \\
\hline 31 & Arunachal Pradesh & 1 & 0 \\
\hline 32 & Nagaland & 1 & 0 \\
\hline 33 & Mizoram & 1 & 0 \\
\hline \multicolumn{2}{|c|}{$\begin{array}{c}\text { Total number of confirmed } \\
\text { cases in India }\end{array}$} & 67,152 & 2,206 \\
\hline
\end{tabular}

TESTING CENTERS FOR COVID-19 IN INDIA

As of May $6^{\text {th }}, 2020$, there were only 445 laboratories both government and private throughout India that served COVID-19 examinations, as reported by the Indian Council of Medical Research (2020). The number is certainly relatively small compared to the area of India and the large population. However, the increase in the number of laboratories is quite fast, where on May $3^{\text {rd }}$, 2020 there were only 426 laboratories reported or experienced an increase in 19 laboratories over three days. Overall, the number of testing centers for COVID19 throughout India is presented in Table IV.

Table IV. The number of testing centers for COVID-19 in India per May $6^{\text {th }}, 2020$ (Indian Council of Medical Research, 2020)

\begin{tabular}{llr}
\hline No & $\begin{array}{c}\text { Name of States/ } \\
\text { Union territories }\end{array}$ & $\begin{array}{c}\text { Number of testing } \\
\text { centers for COVID-19 }\end{array}$ \\
\hline 1 & Andhra Pradesh & 48 \\
2 & Arunachal Pradesh & 1 \\
3 & Assam & 7 \\
4 & Bihar & 7 \\
5 & Chandigarh & 3 \\
6 & Chhattisgarh & 5 \\
7 & Delhi & 26 \\
8 & Gujarat & 24 \\
9 & Goa & 3 \\
10 & Haryana & 18 \\
\hline
\end{tabular}

\begin{tabular}{llr}
\hline 11 & Himachal Pradesh & 5 \\
12 & Jammu \& Kashmir & 5 \\
13 & Jharkhand & 5 \\
14 & Karnataka & 30 \\
15 & Kerala & 20 \\
16 & Maharashtra & 58 \\
17 & Madhya Pradesh & 13 \\
18 & Manipur & 2 \\
19 & Meghalaya & 1 \\
20 & Mizoram & 1 \\
21 & Nagaland & 2 \\
22 & Odisha & 8 \\
23 & Puducherry & 2 \\
24 & Punjab & 6 \\
25 & Rajasthan & 20 \\
26 & Tamil Nadu & 52 \\
27 & Telangana & 20 \\
28 & Tripura & 1 \\
29 & Uttar Pradesh & 24 \\
30 & Uttarakhand & 5 \\
31 & West Bengal & 18 \\
32 & Andaman \& Nicobar & 3 \\
& Islands & \\
33 & Dadra \& Nagar Haveli & 1 \\
34 & Sikkim & 1 \\
\hline & &
\end{tabular}

\section{CONCLUSION}

Despite its rapid spread and its deadly effect on some people, COVID-19 still holds the chance to be conquered through the discovery and repurposing of various drug compounds and vaccines. Today the whole world depends entirely on the speed of various laboratories, universities, and the pharmaceutical industry in finding and testing drug compounds that can be relied upon for COVID-19 therapy. Despite the progress that has been made, advances in clinical trials of some drugs such as remdesivir may raise hopes that the discovery of therapies for COVID-19 can be made this year.

\section{REFERENCES}

Algernon Pharmaceuticals. (2020). NP-120 (Ifenprodil). https://algernonpharmaceuticals.com/ipfnp-120/

Ali, I. \& Alharbi, O.M.L. (2020). COVID-19: Disease, management, treatment, and social impact. The Science of The Total Environment, 728, 138861. doi:10.1016/j.scitotenv.2020.138861

APEIRON Biologics. (2020). APEIRON Biologics closes oversubscribed financing round of EUR 17.5 
million for the development of APN01 against COVID-19. $\quad$ https://www.apeironbiologics.com/wp-

content/uploads/2020/06/200602_APEIRO

N_Closing-Financing_ENG_final.pdf

Astuti, I. \& Ysrafil. (2020). Severe Acute Respiratory Syndrome Coronavirus 2 (SARS-CoV-2): An overview of viral structure and host response. Diabetes and Metabolic Syndrome, [Epub ahead of print]. doi:10.1016/j.dsx.2020.04.020

Baron, S.A., Devaux, C., Colson, P., Raoult, D., \& Rolain, J.M. (2020). Teicoplanin: An Alternative Drug for the Treatment of COVID-19? International Journal of Antimicrobial Agents, 55(4), 105944. doi:10.1016/j.ijantimicag.2020.105944

BeyondSpring. (2020). BeyondSpring Files for Patent Protection on BPI-002 for the Treatment of Viral Infections Including COVID-19. https://www.beyondspringpharma.com/pr essreleases/info.aspx?itemid=2212

Biocryst Pharmaceuticals. (2020). Galidesivir. https://www.biocryst.com/ourprogram/galidesivir/

Bioxytran. (2020). Bioxytran Seeking Partners for Late Stage Treatment of Wuhan Coronazirus using BXT-25. https://www.bioxytraninc.com/pressreleases/bioxytran-seeking-partners-for-latestage-treatment-of-wuhan-coronavirus-usingbxt-25

Cao, B., Wang, Y., Wen, D., Liu, W., Wang, J., Fan, G., Ruan, L., Song, B., Cai, Y., Wei, M., Li X., Xia, J., Chen, N., Xiang, J., Yu, T., Bai, T., Xie, X., Zhang, L., Li, C., Yuan, Y., Chen, H., Li, H., Huang, H., Tu, S., Gong, F., Liu, Y., Wei, Y., Dong, C., Zhou, F., Gu, X., Xu, J., Liu, Z., Zhang, Y., Li, H., Shang, L., Wang, K., Li, K., Zhou, X., Dong, X., Qu, Z., Lu, S., Hu, X., Ruan, S., Luo, S., Wu, J., Peng, L., Cheng, F., Pan, L., Zou, J., Jia, C., Wang, J., Liu, X., Wang, S., Wu, X., Ge, Q., He, J., Zhan, H., Qiu, F., Guo, L., Huang, C., Jaki, T., Hayden, F.G., Horby, P.W., Zhang, D., \& Wang, C. (2020). A Trial of Lopinavir-Ritonavir in Adults Hospitalized with Severe Covid-19. The New England Journal of Medicine, 382, 1787-1799. doi:10.1056/NEJMoa2001282

Cui, J., Li, F., \& Shi, Z.L. (2019). Origin and evolution of pathogenic coronaviruses. Nature Reviews
Microbiology, $\quad$ 17(3),

doi:10.1038/s41579-018-0118-9

181-192.

Djalante, R., Lassa, J., Setiamarga, D., Sudjatma, A., Indrawan, M., Haryanti, B., Mahfud, C., Sinapoy, M.S., Djalante, S., Rafliana, I., Gunawan, L.A., Surtiari, G.A.K., \& Warsilah, H. (2020). Review and analysis of current responses to COVID-19 in Indonesia: Period of January to March 2020. Progress in Disaster Science, $\quad 6,10091$. doi:10.1016/j.pdisas.2020.100091

Doremalen, N.V., Lambe, T., Spencer, A., BeljiRammerstorfer, S., Purusthotham, J.N., Port, J.R., Avanzato, V., Bushmaker, T., Flaxman, A., Ulaszewska, M., Feldmann, F., Allen, E.R., Sharpe, H., Schulz, J., Holbrook, M., Okumura, A., Meade-White, K., Perez-Perez, L., Bissett, C., Gilbride, C., Williamson, B.N., Rosenke, R., Long, D., Ishwarbhai, A., Kailath, R., Rose, L., Morris, S., Powers, C., Lovaglio, J., Hanley, P.W., Scott, D., Saturday, G., de Wit, E., Gilbert, S.C., \& Munster, V.J. (2020). ChAdOx1 nCoV19 vaccination prevents SARS-CoV-2 pneumonia in rhesus macaques. BioRXiv. Preprint, 093195. doi:10.1101/2020.05.13.093195

Duddu, P. (2020). Coronavirus treatment: Vaccines/drugs in the pipeline for COVID-19. https://www.clinicaltrialsarena.com/analysi s/coronavirus-mers-cov-drugs/

El-Aziz, T.M.A. \& Stockand, J.D. (2020). Recent progress and challenges in drug development against COVID-19 coronavirus (SARS-CoV-2) - an update on the status. Infection, Genetics and Evolution, 104327. doi:10.1016/j.meegid.2020.104327

Gautret, P., Lagier, J.C., Parola, P., Hoang, V.T., Meddeb, L., Mailhe, M., Doudier, B., Courjon, J., Giordanengo, V., Vieira, V.E., Dupont, H.T., Honore, S., Colson, P., Chabriere, E., La Scola, B., Rolain, J.M., Brouqui, P., \& Raoult, D. (2020). Hydroxychloroquine and Azithromycin as a Treatment of COVID-19: Results of an OpenLabel Non-Randomized Clinical Trial. International Journal of Antimicrobial Agents, 105949. doi:10.1016/j.ijantimicag.2020.105949

Guner, R., Hasanoglu, I., \& Aktas, F. (2020). COVID-19: Prevention and control measures in community. Turkish Journal of Medical Sciences, 50(3), 571-577. doi:10.3906/sag-2004-146 
Guo, Y.R., Cao, Q.D., Hong, Z.S., Tan, Y.Y., ChenS.D., Jin, H.J., Tan, K.S., Wang, D.Y., \& Yan, Y. (2020). The origin, transmission and clinical therapies on coronavirus disease 2019 (COVID-19) outbreak - an update on the status. Military Medical Research, 7, 11. doi:10.1186/s40779-02000240-0

Indian Council of Medical Research. (2020). Total Operational (initiated independent testing) Laboratories reporting to ICMR. https://www.icmr.gov.in/pdf/covid/labs/ COVID_19_Testing_Labs_06052020.pdf

Innovation Pharmaceuticals. (2020). Brilacidin. http://www.ipharminc.com/brilacidin-1

Khan, S., Siddique, R., Shereen, M.A., Ali, A., Liu, J., Bai, Q., Bashir, N., \& Xue, M. (2020a). Emergence of a Novel Coronavirus, Severe Acute Respiratory Syndrome Coronavirus 2: Biology and Therapeutic Options. Journal of Clinical Microbiology, $\quad$ 58(5), $\quad$ 00187-20. doi:10.1128/JCM.00187-20

Khan, S., Nabi, G., Han, G., Siddique, R., Lian, S., Shi, H., Bashir, N., Ali, A., \& Shereen, M.A. (2020b). Novel coronavirus: how things are in Wuhan. Clinical Microbiology and Infection, 26(4), 399400. doi:10.1016/j.cmi.2020.02.005

Lauer, S.A., Grantz, K.H., Bi, Q., Jones, F.K., Zheng, Q., Meredith, H.R., Azman, A.S., Reich, N.G., \& Lessler, J. (2020). The Incubation Period of Coronavirus Disease 2019 (COVID-19) From Publicly Reported Confirmed Cases: Estimation and Application. Annals of Internal Medicine, 172(9), 577-582. doi:10.7326/m200504

Li, H., Liu, S.M., Yu, X.H., Tang, S.L., \& Tang, C.K. (2020). Coronavirus disease 2019 (COVID-19): current status and future perspectives. International Journal of Antimicrobial Agents, 105951. doi:10.1016/j.ijantimicag.2020.105951

Liu, J., Liao, X., Qian, S., Yuan, J., Wang, F., Liu, Y., Wang, Z., Wang, F.S., Liu, L., \& Zhang, Z. (2020a). Community Transmission of Severe Acute Respiratory Syndrome Coronavirus 2, Shenzhen, China, 2020. Emerging Infectius Diseases, 26(6), [Epub ahead of print]. doi:10.3201/eid2606.200239

Liu, J., Cao, R., Xu, M., Wang, X., Zhang, H., Hu, H., Li, Y., Hu, Z., Zhong, W., \& Wang, M. (2020b).
Hydroxychloroquine, a less toxic derivative of chloroquine, is effective in inhibiting SARSCoV-2 infection in vitro. Cell Discovery, 6, 16. doi:10.1038/s41421-020-0156-0

Magro, G. (2020). SARS-CoV-2 and COVID-19: Is interleukin-6 (IL-6) the 'culprit lesion' of ARDS onset? What is there besides Tocilizumab? SGP130Fc. Cytokine: $X, 2(2), 100029$. doi:10.1016/j.cytox.2020.100029

Mantlo, E., Bukreyeva, N., Maruyama, J., Paessler, S., \& Huang, C. (2020). Antiviral activities of type I interferons to SARS-CoV-2 infection. Antiviral Research, 179, 104811. doi:10.1016/j.antiviral.2020.104811

Megarbane, B. (2020). Chloroquine and hydroxychloroquine to treat COVID-19: between hope and caution. Clinical Toxicology, 1080(10), 1-3. doi:10.1080/15563650.2020.1748194

Mensa, B., Howell, G.L., Scott, R., \& DeGrado, W.F. (2014). Comparative Mechanistic Studies of Brilacidin, Daptomycin, and the Antimicrobial Peptide LL16. Antimicrobial Agents and Chemotherapy, 58(9), 5136-5145. doi:10.1128/AAC.02955-14

Moderna. (2020). Moderna Advances Late-Stage Development of its Vaccine (mRNA-1273) Against COVID-19.

https://investors.modernatx.com/newsreleases/news-release-details/modernaadvances-late-stage-development-its-vaccinemrna-1273

Morawska, L. \& Cao, J. (2020). Airborne transmission of SARS-CoV-2: the world should face the reality. Environment International, 105730. doi:10.1016/j.envint.2020.105730

Norrie, J.D. (2020). Remdesivir for COVID-19: challenges of underpowered studies. The Lancet, 395(10236), 1525-1527. doi:10.1016/S01406736(20)31023-0

Omer, S., Ali, S., \& Babar, Z.D. (2020). Preventive measures and management of COVID-19 in pregnancy. Drugs and Therapy Perspectives, 1-4. doi:10.1007/s40267-020-00725-x

Pal, M., Berhanu, G., Desalegn, C., \& Kandi, V. (2020). Severe Acute Respiratory Syndrome 
Coronavirus-2 (SARS-CoV-2): An Update. Cureus, 12(3), e7423. doi:10.7759/cureus.7423

Pawar, A.Y. (2020). Combating Devastating COVID -19 by Drug Repurposing. International Journal if Antimicrobial Agents, 105984. doi:10.1016/j.jiantimicag.2020.105984

Peng, X., Xu, X., Li, Y., Cheng, L., Zhou, X., \& Ren, B. (2020). Transmission routes of 2019-nCoV and controls in dental practice. International Journal of Oral Science, 12, 9. doi:10.1038/s41368-0200075-9

Regeneron Pharmaceuticals. (2020). Corporate Overview. https://investor.regeneron.com/staticfiles/c1be21c5-bd18-45e4-b8ba-e09e3755fdf5

Rockx, B., Kuiken, T., Herfst, S., Bestebroer, T., Lamers, M.M., Munnink, B.B.O., de Meulder, D., van Amerongen, G., van den Brand, J., Okba, N.M.A., Schipper, D., van Run, P., Leitjen, L., Sikkema, R., Verschoor, E., Verstrepen, B., Bogers, W., Langermans, J., Drosten, C., van Vlissingen, M.F., Fouchier, R., de Swart, R., Koopmans, M., \& Haagmans, B.L. (2020). Comparative pathogenesis of COVID-19, MERS, and SARS in a nonhuman primate model. Science, eabb7314. doi:10.1126/science.abb7314

Sandra, R. (2020). Airway Therapeutics Announces Filing with NIH To Evaluate AT-100 as a Therapy for Novel Coronavirus. https://www.airwaytherapeutics.com/airw ay-therapeutics-announces-filing-with-nih-toevaluate-at-100-as-a-therapy-for-novelcoronavirus/

Seah, I., Su, X., \& Lingam, G. (2020). Revisiting the dangers of the coronavirus in the ophthalmology practice. Eye, [Epub ahead of print]. doi:10.1038/s41433-020-0790-7

Singhal, T. (2020). A Review of Coronavirus Disease-2019 (COVID-19). Indian Journal of Pediatrics, 8(4), 281-286. doi:10.1007/s12098-020-03263-6

Synairgen Research. (2020). Synairgen to start trial of SNG001 in COVID-19 imminently. https://www.synairgen.com/wpcontent/uploads/2020/03/200318Synairgen-to-start-trial-of-SNG001-inCOVID-19-imminently-.pdf
Takeda. (2020). Rajeev Venkayya, President, Global Vaccine Business Unit on the latest on the Coronavirus and Takeda.

https://www.takeda.com/newsroom/featur ed-topics/rajeev-venkayya-president-globalvaccine-business-unit-on-the-latest-on-thecoronavirus-and-takeda/

Tay, M.Z., Poh, C.M., Renia, L., MacAry, P.A., \& Ng, L.F.P. (2020). The trinity of COVID-19: immunity, inflammation and intervention. Nature Reviews Immunology, 1-12. doi:10.1038/s41577-020-0311-8

Tiziana Life Sciences. (2020). Tiziana Lifesciences Develops Novel Investigational Treatment for Patients Infected with COVID-19 Utilizing Direct Delivery of Anti-Interlukin-6-Receptor Monoclonal Antibodies.

https://www.globenewswire.com/newsrelease/2020/04/09/2014044/0/en/TizianaLifesciences-Develops-Novel-InvestigationalTreatment-For-Patients-Infected-withCOVID-19-Utilizing-Direct-Delivery-of-AntiInterlukin-6-Receptor-MonoclonalAntibodies.html

Tonix Pharmaceuticals. (2020). TNX-1800 (Coronavirus Vaccine).

https://www.tonixpharma.com/pipeline/tn x-1800-coronavirus-vaccine

Walls, A.C., Park, Y.J., Tortorici, M.A., Wall, A., McGuire, A.T., \& Veesler, D. (2020). Structure, Function, and Antigenicity of the SARS-CoV-2 Spike Glycoprotein. Cell, 181(2), 281-292. doi:10.1016/j.cell.2020.02.058

Wang, Q., Zhang, Y., Wu, L., Niu, S., Song, C., Zhang, Z., Lu, G., Qiao, C., Hu, Y., Yuen, K.Y., Wang, Q., Zhou, H., Yang, J., \& Qi, J. (2020a). Structural and Functional Basis of SARS-CoV-2 Entry by Using Human ACE2. Cell, [Epub ahead of print]. doi:10.1016/j.cell.2020.03.045

Wang, S.X., Wang, Y., Lu, Y.B., Li, J.Y., Song, Y.J., Nyamgerelt, M., \& Wang, X.X. (2020b). Diagnosis and treatment of novel coronavirus pneumonia based on the theory of traditional Chinese medicine. Journal of Integrative Medicine, [Epub ahead of print]. doi:10.1016/j.joim.2020.04.001

Wang, Y., Zhang, D., Du, G., Du, R., Zhao, J., Jin, Y., Fu, S., Gao, L., Cheng, Z., Lu, Q., Hu, Y., Luo, G., Wang, K., Lu, Y., Li, H., Wang, S., Ruan, S., 
Yang, C., Mei, C., Wang, Y., Ding, D., Wu, F., Tang, X., Ye, X., Ye, Y., Liu, B., Yang, J., Yin, W., Wang, A., Fan, G., Zhou, F., Liu, Z., Gu, X., Xu, J., Shang, L., Zhang, Y., Cao, L., Guo, T., Wan, Y., Qin, H., Jiang, Y., Jaki, T., Hayden, F.G., Horby, P.W., Cao, B., \& Wang, C. (2020c). Remdesivir in adults with severe COVID-19: a randomised, double-blind, placebo-controlled, multicentre trial. The Lancet, 395(10236), 15691578. doi:10.1016/S0140-6736(20)31022-9

Wang, M., Cao, R., Zhang, L., Yang, X., Liu, J., Xu, M., Shi, Z., Hu, Z., Zhong, W., \& Xiao, G. (2020d). Remdesivir and chloroquine effectively inhibit the recently emerged novel coronavirus (2019$\mathrm{nCoV})$ in vitro. Cell Research, 30, 269-271. doi:10.1038/s41422-020-0282-0

de Wit, E., Feldmann, F., Okumura, A., Horne, E., Haddock, E., Saturday, G., Scott, D., Erlandson, K.J., Stahl, N., Lipsich, L., Kyratsous, C.A., \& Feldmann, H. (2018). Prophylactic and Therapeutic Efficacy of $\mathrm{mAb}$ Treatment Against MERS-CoV in Common Marmosets. Antiviral Research, 156, 64-71. doi:10.1016/j.antiviral.2018.06.006

World Health Organization. (2020). DRAFT landscape of COVID-19 candidate vaccines-20 April 2020. https://www.who.int/blueprint/prioritydiseases/key-action/novel-coronaviruslandscape-ncov.pdf?ua $=1$

Worldometer. (2020). COVID-19 Coronavirus Pandemic. https://www.worldometers.info/coronaviru s/

Xu, J., Zhao, S., Teng, T., Abdalla, A.E., Zhu, W., Xie, L., Wang, Y., \& Guo, X. (2020). Systematic Comparison of Two Animal-to-Human Transmitted Human Coronaviruses: SARSCoV-2 and SARS-CoV. Viruses, 12(2), 244. doi:10.3390/v12020244

Yi, Y., Lagniton, P.N.P., Ye, S., Li, E., \& Xu, R.H. (2020). COVID-19: what has been learned and to be learned about the novel coronavirus disease. International Journal of Biological Sciences, 16(10), 1753-1766. doi:10.7150/ijbs.45134

Yuen, K.S., Ye, Z.W., Fung, S.Y., Chan, C.P., \& Jin, D.Y. (2020). SARS-CoV-2 and COVID-19: The most important research questions. Cell and Bioscience, 10, 40. doi:10.1186/s13578-02000404-4
Zhai, P., Ding, Y., Wu, X., Long, J., Zhong, Y., \& Li, Y. (2020). The epidemiology, diagnosis and treatment of COVID-19. International Journal of Antimicrobial Agents, 105955. doi:10.1016/j.jiantimicag.2020.105955

Zhang, H., Penninger, J.M., Li, Y., Zhong, N., \& Slusky, A.S. (2020). Angiotensin-converting enzyme 2 (ACE2) as a SARS-CoV-2 receptor: molecular mechanisms and potential therapeutic target. Intensive Care Medicine, 46(4), 586-590. doi:10.1007/s00134-020-05985-9

Zhou, P., Yang, X., Wang, X. Hu, B., Zhang, L., Zhang, W., Si, H.R., Zhu, Y., Li, B., Huang, C.L., Chen, H.D., Chen, J., Luo, Y., Guo, H., Jiang, R.D., Liu, M.Q., Chen, Y., Shen, X.R., Wang, X., Zheng, X.S., Zhao, K., Chen, Q.J., Deng, F., Liu, L.L., Yan, B., Zhan, F.X., Wang, Y.Y., Xiao, G.F., \& Shi., Z.L. (2020). A pneumonia outbreak associated with a new coronavirus of probable bat origin. Nature 579(7798), 270-273. doi:10.1038/s41586-020-2012-7

Zumla, A., Chan, J.F., Azhar, E.I., Hui, D.S., \& Yuen, K.Y. (2016). Coronaviruses - drug discovery and therapeutic options. Nature Reviews Drug Discovery, 15(5), 327-347. doi:10.1038/nrd.2015.37 